\title{
SCIENTIFIC TRUTH AND OCCULT TRADITION: THE MEDICAL WORLD OF EBENEZER SIBLY (1751-1799)
}

by

\section{ALLEN G. DEBUS*}

HISTORIANS of science and medicine have frequently pictured the eighteenth century exclusively in terms of the triumph of Newtonian physics and the mechanical world view. According to this interpretation, the role of the creator was to be severely diminished in the world about us, and, in contrast to the vitalistic philosophies of the sixteenth and early seventeenth centuries, religion was to be divorced from science.

However, recent research has pointed to the fact that there was a persistent criticism of those who advocated a purely clockwork universe. Indeed, if we are to understand fully the Romantic science and medicine of the late eighteenth and early nineteenth centuries, we must examine in detail the works of those who offered other roads to travel. Because of the more mystical flavour of the works of the Naturphilosophen, it is of particular importance to examine deeply-rooted nonmechanical themes that had persisted from the Renaissance through the eighteenth century, such as alchemy, astrology, and natural magic. Here were to be found religious and mystical concepts that were divorced from the establishment science of the Enlightenment, but which were to be rediscovered by the Romantics.

In this context, Ebenezer Sibly is an author of special interest. Here we find a physician who was well read in the scientific and medical literature of his own day. He referred repeatedly, among others, to Priestley, Buffon, and Franklin in the sciences, and to Heberden, Dobson, and van Swieten in medicine. Indeed, Sibly thought of himself as a member of the medical establishment. He proudly displayed his M.D. degree and he referred to himself as a Fellow of the "Royal Society of Physicians of Aberdeen". But Sibly was also convinced that this science was insufficient in itself. For deeper truths one must turn to subjects that were of little interest to the mechanists of the academies in London and Paris. Sibly believed that the harmonies of the great and small worlds taught by earlier Paracelsians and the Hermeticists were literally true and that scholars should re-examine the long-neglected sciences of

*Allen G. Debus, Ph.D., Morris Fishbein Professor of the History of Science and Medicine, The University of Chicago, and Fellow (1981-1982), The Institute for Research in the Humanities, The University of Wisconsin-Madison.

The research resulting in the present paper was supported in part by a grant from the National Science Foundation (SES 8008919). In abbreviated form it was presented first to the Washington Society for the History of Medicine on 19 March 1981.

The author also wishes to express his gratitude to Dr. Charles Rondle, whom he met after the completion of the first draft of this paper. Dr. Rondle is preparing a bio-bibliography of Ebenezer Sibly and he generously shared the results of his own research with me. It is to be hoped that his work will soon be ready for the press. 


\section{A. G. Debus}

astrology, alchemy, and natural magic. He eagerly embraced the teachings of the Freemasons and openly proclaimed his membership in the Harmonic Society of Paris, as association of the disciples of Anton Mesmer.

Thus, while Sibly accepted the fruits of the new science and medicine of his own century, he believed that these discoveries should be joined to the deeper truths to be found in the more mystical philosophies of the Renaissance and antiquity. The seventeenth-century watershed we recognize as producing a new science simply did not exist for him. It is precisely for this reason that Sibly's work sheds light on a difficult period of change in the sciences.

\section{EBENEZER SIBLY (1751-1799)}

Ebenezer Sibly was one of four children. Of his sister we know only of her existence, and of his brother Job we know little more, but Manoah and Ebenezer were both talented scholars. Manoah (1757-1840), seven years the junior of Ebenezer, was to outlive him by forty years. ${ }^{1}$ He was a noted linguist who taught Hebrew, Greek, Latin, and Syriac in addition to having learned shorthand, an accomplishment which permitted him to work in the law courts. A love of books coupled with a need to survive led him to open a bookshop, where he sold his own works on religion, astrology, and astronomy, as well as those of his brother. Manoah's mystical bent was expressed on the one hand in his study of astrology and alchemy, and on the other in his interest in the works of Emanuel Swedenborg (1688-1772). A noted preacher, he took charge of a Swedenborgian congregation in 1790 . He was eventually to find additional employment with the Bank of England; where he rose to the position of principal of the Bank's chancery office in 1815 , a post he held until shortly before his death.

We know much less about the life of Ebenezer, although the current research of Charles Rondle is doing much to enlighten us on the details of his career. ${ }^{2}$ From Sibly's major work on astrology we are informed that he was born in Bristol at 11.23 a.m. on 30 January 1751 (Plate 1). At various times, he resided at Portsmouth, Bristol, London, and Ipswich. He graduated M.D. from King's College, Aberdeen, on 20 April 1792, although there is no evidence that he ever went there. ${ }^{3}$ This was a period of increasing interest in medicine in Aberdeen. A dozen medical students at Marischal College had founded the Aberdeen Medical Society late in 1789, and Sibly may have been invited to join. ${ }^{4}$ The frontispiece portrait of some editions of his Medical mirror refers to his membership in the "Royal College of Physicians in Aberdeen". The Aberdeen Medical Society was far from being a royal college of

\footnotetext{
${ }^{1}$ See the short biography by Edward Irving Carlyle in the Dictionary of National Biography.

${ }^{2}$ Carlyle's short biography of Ebenezer is quite inadequate. However, it is true that there are relatively few references to him. Sibly seldom gave details of his personal life in his books and there seem to be no contemporary biographical accounts. It is for this reason that Dr. Charles J. M. Rondle's research on Sibly's life will be so helpful.

${ }^{3}$ Peter John Anderson (editor), Officers and graduates of University and King's College Aberdeen MVD. $M D C C L X$, Aberdeen, New Spalding Club, 1893, p. 138. Here Sibly is referred as "Chirurgus Londinensis."

'See An account of the Aberdeen Medical Society: containing the laws, regulations \&c., Aberdeen, 1796; and Ella Hill Burton Rodger, Aberdeen doctors at home and abroad: the narrative of a medical school, Edinburgh, Wm. Blackwood, 1893. Rodger does not refer to Sibly. A letter from Colin A. McLaren, Archivist and Keeper of Manuscripts at the Aberdeen University Library, added no new information.
} 


\section{Scientific truth and occult tradition}

physicians, but it was the only society of its kind in that part of Scotland. Publications dated 1790 and later refer to Sibly as a Fellow of the Harmonic Philosophical Society in Paris. In addition to mesmerism, he was active in Freemasonry. He had become a Freemason in 1784, and the dedication to the 1790 edition of $A$ new and complete illustration of the occult sciences was to "the Ancient and Honourable fraternity of Free and Accepted Masons".s Four years later, he dated the dedication of his new edition of Culpeper's English physician: and complete herbal "in the year of Masonry 5798". There are occasional references to his travels and experiences, but, in fact, we know relatively little about the life of this prolific author.

Ebenezer Sibly's published works come to approximately 2,500 quarto pages, and they were frequently reprinted into the early nineteenth century. No single library seems to have a complete collection, and it is possible that not every edition has survived. The earliest publication is the first part of a major work, $A$ new and complete illustration of the celestial science of astrology (Parts 1 and 2, 1784; Part 3, 1787; Part $4,1788) .{ }^{7}$ Some later editions were titled $A$ new and complete illustration of the occult sciences. Other editions followed in rapid succession. The twelfth edition appeared in 1817 , and the last printing I have seen referred to is dated 1826. Extracts were translated into Bengali in 1885.8 The new and complete illustration of the celestial science of astrology was followed by a new book composed of astrological charts and forms, the Uranoscopia: or the pure language of the stars. ${ }^{9}$

Sibly prepared one of the most popular medical works of the period in his edition of Culpeper's English physician: and complete herbal (1789) (Part I, The herbal; Part II, The medical part), which reached a thirteenth edition by $1812 .{ }^{10}$ Late impressions of this herbal no longer have Sibly's name on the title-page. Only slightly less popular was $A$ key to physic and the occult sciences (1794), which had reached a fifth edition in

Ebenezer Sibly. A new and complete illustration of the occult sciences: or, the art of foretelling future events and contingencies, by the aspects, positions, and influences, of the heavenly bodies ... in four parts, London, For the Proprietor, 1790, pp. xi, xii.

Sibly [n.d. (1794?)], op. cit., note 10 below, p. iv.

'This is the composition of Dr. Rondle's copy. Actual references will be made to the following edition: $A$ new and complete illustration of the celestial science of astrology: or, the art of foretelling future events and contingencies by the aspects, positions, and influence of the heavenly bodies. Founded on natural philosophy, scripture, reason and the mathematics, London, Printed for the Proprietor, and sold by W. Nicoll, M. Sibly and E. Sibly, Part 1, 1784; Part 2, [n.d.]; Part 3, 1792, Part 4, 1792.

The work appears as $A$ new and complete illustration of the occult sciences in the 1790 printing. Later editions include those of 1811 (new ed.), 1812, 1813, 1817 (12th ed.), and 1826.

- See the British Library Catalogue.

'E. Sibly, Uranoscopia. Or the pure language of the stars. Unfolded by the motion of the seven erratics, etc. This work is undated, but is listed in the British Library Catalogue as c. 1780. Dr. Rondle is probably correct in dating it c. 1785-1787.

${ }^{10}$ E. Sibly, M.D., Fellow of the Harmonic Philosophical Society at Paris, Culpeper's English physician: and complete herbal. To which are now first added, upwards of one hundred additional herbs, with a display of their medicinal and occult properties, physically applied to the cure of all disorders incident to mankind. To which are annexed, rules for compounding medicine according to the true system of nature: forming $a$ complete family dispensatory, and natural system of physic . . . . London, Printed for the Author, and Sold at the British Directory Office, and by Champante and Whitrow, [n.d., (c. 1794)]. The first edition of this work is dated 1789. It is normally bound with a second part, The medical part. In addition to the 1794 edition, I have used the thirteenth edition of 1812 of the second part (London, J. Adlard for the Proprietors and Sold at the Encyclopedia Office and by Champante and Whitrow, 1812). Other editions include those of $1790,1798,1802,1806,1808,1809,1810,1812$, and 1813. 


\section{A. G. Debus}

1814. ${ }^{11}$ The short Medical mirror (1794) was in its sixth edition by 1814 and it had been translated into german shortly after its initial publication as Medizinischer Spiegel (1796). ${ }^{12}$ Ebenezer Sibly's last major project was the Magazine of natural history comprehending the whole science of animals, plants, and minerals. The first volume of this work appeared in 1796, and the complete set eventually reached fourteen volumes. ${ }^{13}$ However, as in the case of the Herbal, the later volumes appeared without his name as author. In addition to these works, there are a few lesser titles listed in library catalogues and several unpublished manuscripts. ${ }^{14}$

\section{A SYSTEM OF NATURE}

Ebenezer Sibly was a practising physician of the Enlightenment. Yet, like many of his seventeenth-century predecessors, he sought a system of nature different from that of the mechanists. In a very real sense his work is reminiscent of that of Robert Fludd (1574-1637) and Athanasius Kircher (1601-1680) in accepting the essential harmony of the macrocosm and the microcosm, and in being stamped by strong religious convictions.

Sibly believed that true knowledge would lead to an understanding of our Creator: "Wisdom is the light of Reason, and the bond of Peace. It assimilates Man to God, and elevates his mind above unworthy pursuits. . . . wisdom and understanding provide us with wings, whereby to soar above the earth; to contemplate the works of creation to discern the mysteries of divinity, and converse with angels." 15 He did not deny the importance of reason in this quest for knowledge, and he was an avid student of the current scientific and medical literature. He was fully aware of the importance of observation and experiment in the study of nature, and he claimed that for ten years he had carried out chemical experiments daily in his search for the medical properties of plants and minerals. ${ }^{16}$ But the simple evidence of the senses was not enough. Man must go further through a study of the

... occult properties and qualities of all things. ... they lead to a comprehensive idea of those occult causes and effects, which act most, though they are the least seen; and whereby the human understand-

$"$ E. Sibly, M.D., F.R.H.S., A key to physic and the occult sciences. Opening to mental view, the system and order of the interior and exterior heavens; the analogy betwixt angels and the spirits of men; and the sympathy between celestial and terrestrial bodies. . . The whole forming an interesting supplement to Culpeper's Family physician . . ., 5th ed., London, Printed by W. Lewis for C. Jones (late Wilkes), 1814. The first edition is believed to be that of 1794 and there are other editions of 1800,1802 , and 1806.

12 E. Sibly, M.D., F.R.H.S., The medical mirror; or a treatise on the impregnation of the human female. Showing the origin of diseases, and the principles of life and death. With remarks on the general effects of sea-bathing, 5th ed., London, For the Proprietor, by Lewis and Hamblin and sold by Champante and Whitrow, 1807. Other editions date from 1794?, 1796?, 1800? (2nd), 1800 (4th), and 1814. The final English edition was printed as late as 1840 . The German edition was printed by C. G. Hilscher in 1796.

${ }^{13} \mathrm{E}$. Sibly, Magazine of natural history comprehending the whole science of animals, plants, and minerals; divided into distinct parts, the characters separately described, and systematically arranged, vol. 1, London, Printed for the Proprietor, and Sold by Champante and Whitrow and at the British Directory Office, 1796.

${ }^{14}$ Carlyle refers to a manuscript by Sibly containing the horoscopes of Pitt, Fox, and Sheridan while "The Fountain Allegory of Bernard of Treviso From the Manuscript translation of Ebenezer Sibley /sic/ in the Ferguson Collection" has recently been made available in the Hermetic Journal, summer 1979, no. 4, 25-28.

is Sibley (1814), op. cit., note 11 above, p. 1.

16 Ibid., p. 34. The claim cannot be substantiated. 


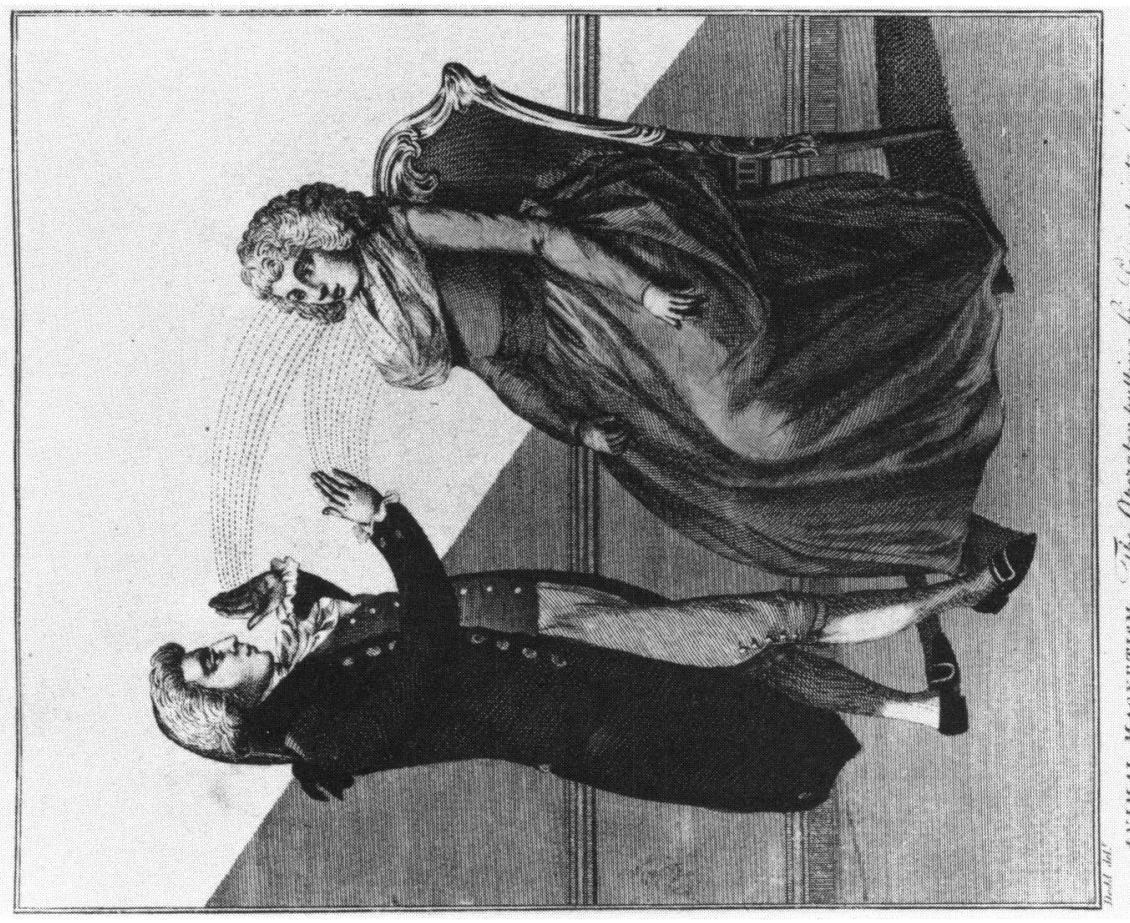

2

बे

ऽ

충

站.

通

过

$\stackrel{\infty}{1} \stackrel{\infty}{.}$

ㅌํㅇ흉

노오

苍 远

हิ

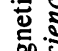

$\stackrel{\Xi}{E}$

즁

这

ㄴ

产

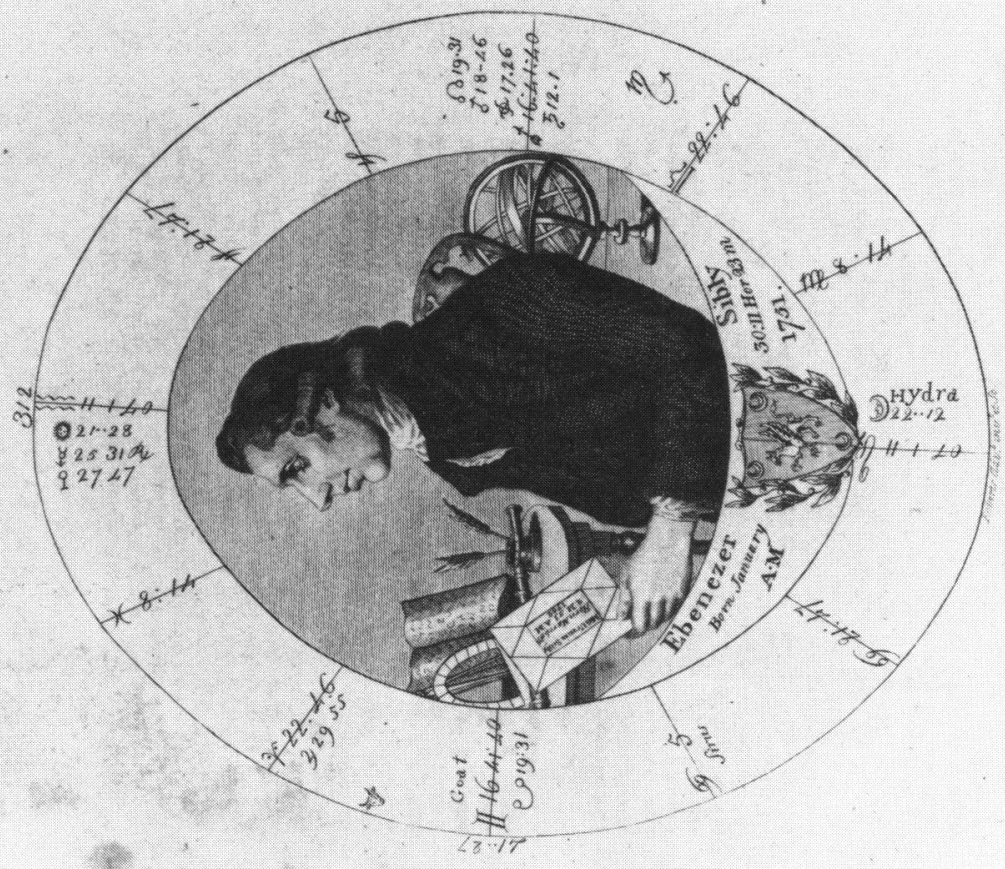

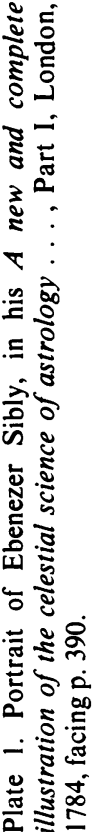


$1: 51$

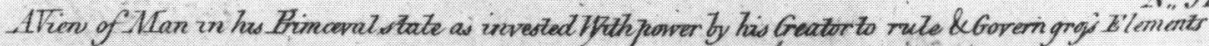

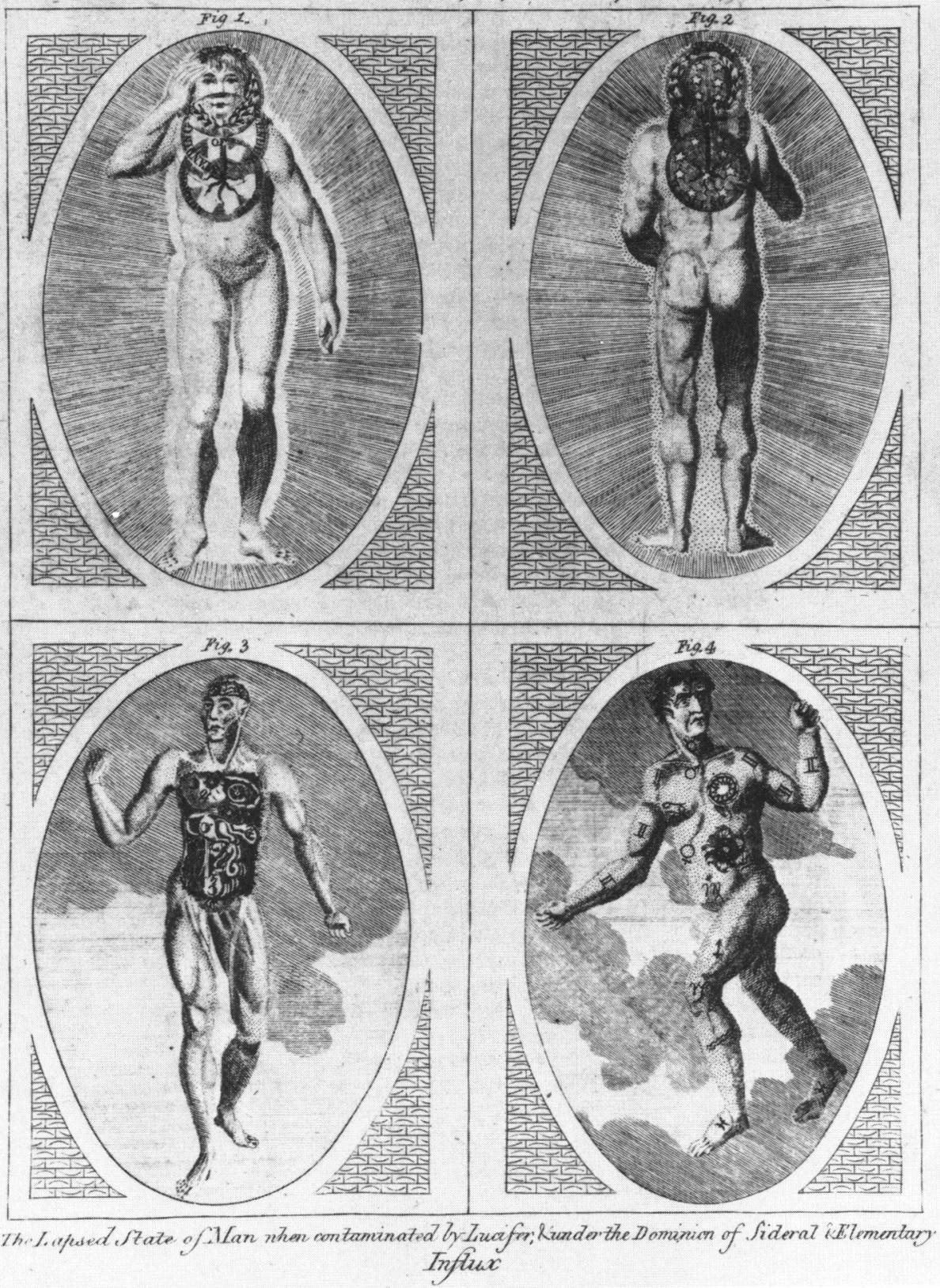

Plate 3. The four pictures of man and disease (primeval and after the fall). From Ebenezer Sibly, A complete illustration of the astrological and occult sciences, Part IV, London, [n.d.], facing p. 1098. 


\section{Scientific truth and occult tradition}

ing is enlightened and improved, and the mind enriched with those divine precepts, which lead to a manifestation of that FIRST and omnipotent CAUSE to whose power all second causes are subservient, and operate but as the agents of his Will; and under whose provident care and sufferance we see, feel, move, speak, and have our being! ${ }^{17}$

Indeed, we are truly blessed as we pursue our study of the mysteries around us “. . . of the astonishing sympathy and antipathy betwixt heavenly and earthly substances; of the wonderful harmony and construction of the celestial bodies; of the nature and qualities of our own existence, and the propagation of our species; of the occult properties implanted in all created beings; and the end for which they are and were created!'"18

Sibly's universe was based upon his interpretation of Holy Scripture and philosophy. It was a vitalistic system in which the will of the Godhead

$\ldots$ is communicated to the angels and spirits, and instantaneously conducted to the Anima Mundi. Round the whole, as an atmosphere round a planet, the Anima Mundi, or universal Spirit of Nature is placed; which receiving the impressions or ideas of the Divine Mind, conducts them onward, to the remotest parts of the universe; to infinity itself; to, and upon, and through, all bodies, and to all God's works. This Anima Mundi is therefore what we understand of Nature, of Providence, of the presence of God, and the fountain or seat of all second causes, being, as it were, the Eye of God, or medium between God and all created things. ${ }^{19}$

Earlier authors, from the ancient philosophers to René Descartes (1596-1650) and Nicolas Malebranche (1638-1715), had discussed the meaning of Nature in apparently contradictory accounts. ${ }^{20}$ Sibly disagreed, for in reality they all

... meant one and the same thing, only giving different explanations of the same ideas; and if their arguments are closely pursued, and compared with each other, they will all tend to show, that the anima mundi, or soul of the universe, was what they meant by Nature.

This anima mundi, as we have before seen, is a medium investing the whole interior heavens, and consists of a pure ethereal substance, or spirit: which ... moves and governs the heavens, and heavenly bodies, stars, and planets; .... From the celestial regions, the same influx of pure ethereal spirit descends into every part of the immeasurable space, and is diffused through the mass of this world, informing, actuating, and uniting the different parts thereof into various substances; and being the primary source of life, every-where breathing a spirit like itself, it pervades all elementary bodies, and, intimately mixing with all the minute atoms thereof, constitutes the power or instrument we call Nature, forming, fashioning, and propagating, all things, conformably to the ideas or will of the Divine Mind in the first act of creation. ${ }^{21}$

Sibly was deeply versed in traditional alchemical literature. He translated an alchemical allegory of Bernard of Treviso (1406-1490), and his plates reflect the illustrations to be found in the Amphitheatrum sapientiae of Heinrich Khunrath (1560-1605).22 Thus it is no surprise that he presented a symbolic alchemical representation of the Universal Spirit of Nature in the Key to physic and the occult sciences. ${ }^{23}$ But Sibly also knew the most recent scientific literature and he wrote that,

${ }^{17}$ Ibid., p. 3.

18 Ibid.

19 Ibid., pp. 8-9.

${ }^{20}$ Ibid., p. 9.

${ }^{21}$ Ibid., p. 12.

${ }^{22}$ For the Trevisan manuscript see note 14 above. The frontispiece to $A$ key to physic is derived from the folding plate of the "Porta Amphitheatri Sapientiae Aeternae" in Heinrich Khunrath. Amphitheatrum sapientiae aeternae .... . . Hanau, Guilielmus Antonius, 1609. There is an alchemical and Rosicrucian scrapbook by Ebenezer Sibly at the Wellcome Library entitled "The dumb made to speak" dated 17y1.

${ }^{23}$ Sibly (1814), op. cit., note 11 above, plate opposite p. 28. 


\section{A. G. Debus}

"The vivifying principle contained in the atmosphere, so essential to the support of flame, as well as animal life, concerning which authors have proposed so many conjectures, is nothing else but that pure oxygenated fluid lately discovered by that ingenious philosopher Lavoisier."24

Like earlier alchemists, Sibly accepted the concept of a prime matter. The Aristotelian elements, Earth, Water, Air, and Fire, could be accepted as philosophically pure substances, but for the current state of knowledge one needed also to consult authors such as Herman Boerhaave (1668-1738), Pieter van Musschenbroek (1692-1761), Joseph Priestley (1733-1804), Benjamin Franklin (1706-1790), Stephen Hales (1677-1761), Philippe de la Hire (1640-1718), the Comte de Buffon (1707-1788), and Sir Isaac Newton (1642-1727). Thus, in addition to the Aristotelian concept of a pure elemental air, the recent literature confirmed that the atmosphere is a mixture of "corpuscles of various kinds." 25 These include

\footnotetext{
Dephlogisticated air, the oxygenous gas, or vital air, of the new chemistry . . Phlogisticated air, or azotic gas ... Fixed air, or carbonic acid gas ... Inflammable air, (hydrogenous gas) ... Nitrous air, or nitrous gas ... Marine acid air, the muriatic acid gas of the new chemistry ... Dephlogisticated marine acid air, or oxygenated muriatic acid gas, Alkaline air, or ammoniacal gas ... [and] Hepatic air, or sulphureous acid gas ....26
}

However, the atmosphere is composed primarily of "dephlogisticated and phlogisticated air, and thus supports and sustains both animal life and vegetation." 27 We should understand that the atmospheric "air is an instrument which nature is universally applying in all her works, consequently a knowledge of its properties seems highly necessary not only to the chemist and physician, but to the philosopher and divine." 28

Sibly's primal matter was atomistic in form. ". . . there is one catholic or universal matter, called corpuscles or atoms, filling all space, which is an extended, impenetrable, and divisable, substance, common to all bodies, and capable of all forms; infinitely harder than any of the sensible porous bodies compounded of them; even so hard, as never to wear, or break in pieces; no other power being able to divide what God made one in the first creation." 29 In order to explain the variety of natural bodies, Sibly assigned motion to the atoms. In addition, they have a vis inertiae, and are moved by active principles "such as that of gravity, and that which causes fermentation, and the cohesion and sympathy of bodies." 30

This view of the first principles of matter accounts for an infinity of phenomena, otherwise inexplicable,
and points out all the occult operations in nature, by sympathy, antipathy, fascination, cohesion,
coagulation, dissolution, \&c. for since these corpuscles are every where and at all times in motion,
issuing from and cohering to all bodies that fall in their way; and since they are operated upon and
diversely altered by the four elements proper to this world; and these elements again by rays of light,
heat, and influx of the anima mundi and celestial bodies, all the vicissitudes of nature are deduced from
them;...... Among these natural laws are Sympathy and Antipathy. Sibly affirmed that the truths of sympathetic action were well known through the mutual effect of the

24 Ibid., p. 152.

${ }^{2 s}$ Sibly, op. cit., note 7 above, Part 1 (1784), p. 60.

${ }^{26}$ Sibly (1814), op cit., note 11 above, p. 166.

${ }^{27}$ Ibid., p. 167.
23 Sibly, op. cit., note 7 above, Part 1 (1784), p. 63.

Sibly (1814), op. cit., note 11 above, p. 27.

30 Ibid.

31 Ibid., p. 28 


\title{
Scientific truth and occult tradition
}

lodestone and iron, cure by sympathy, and by many other observations to be found in the works of physicians and scientists. ${ }^{32}$ They were all to be explained most satisfactorily through atomism. But all of this implied a closely-knit universe seldom expressed in the eighteenth century. Sibly's model of nature was to be found in "the construction of a watch, consisting of many small wheels, regulated by one masterwheel, or first mover, which being wound up at the creation, with the line of time, of a seemingly infinite length, has ever since been winding off, unto the present hour...." ${ }^{\prime 3}$ The same occurs in man, who is "... as it were, a little world within himself; and though he stand but as one wheel in the frame of the great world, yet within this one there seems many thousands of wheels, especially in enterprising people, which appear to move one within another almost ad infinitum, till the thread turned on the outer wheel break, or else be wound off, and there they make a stop, and die." 34

\section{THE MACROCOSMIC WORLD}

Convinced of the harmony of all parts of the universe, Sibly repeatedly insisted on the essential place of God in his creation. Not only the beauty of nature, but its complexity, proved the existence and the wisdom of God. Indeed, this was clearly seen in the framework of our own celestial system, which he accepted as having been established by Copernicus in 1543. It is this system rather than the ancient geocentrism of Ptolemy and Aristotle

\begin{abstract}
... which is now received and approved as the only true one; because most agreeable to the tenor of nature in all her actions; for by the two motions of the earth, all the phenomena of the heavens are resolved, which, by other hypothesis are inexplicable, without a great number of other motions contrary to philosophical reasoning.... The harmony which runs through the solar system, wonderfully confirms this hypothesis, viz. that the motions of all the planets, both primary and secondary, are governed and regulated by one and the same law, which is, that the squares of the periodical times of the primary planets, are to each other as the cubes of their distances from the sun; and likewise the squares of the periodical times of the secondaries of any primary, are to each other as the cubes of their distances from that primary. ${ }^{35}$
\end{abstract}

Sibly's interest in celestial events led him to discuss the astronomical as well as the astrological knowledge of the planets in some detail. He also devoted a long section to comets, which, he insisted, were a necessary source for the earthly vital spirit. Speaking of the vapours that accompany them, he noted that Sir Isaac Newton had suggested in his Principia mathematica that when they are dilated, rarefied, and diffused throughout the celestial regions, they

may probably, by little and little, by means of their own gravity, be attracted down to the planets, and become intermingled with their atmospheres. He adds likewise, that, for the conservation of the water and moisture of the planets, comets seem absolutely requisite; from whose condensed vapours and exhalations, all that moisture, which is spent in vegetations and putrefactions, and turned into dry earth, \&c. may be resupplied and recruited. For all vegetables grow and increase wholly from fluids; and, again, as to their greatest part, turn, by putrefaction, into earth again; an earthy slime being perpetually precipitated to the bottom of putrefying liquors. Hence, the quantity of dry earth must continually increase, and the moisture of the globe decrease, and at last be quite evaporated, if it has not a continual supply from some part or other of the universe. And I suspect, adds our great author, that the spirit, which makes the finest, subtilest, and the best, part of our air, and which is absolutely requisite for the

${ }^{32}$ Ibid., pp. $28 \mathrm{ff}$.

${ }^{33}$ Sibly, op. cit., note 7 above, Part 1 (1784), p. 42.
${ }^{34}$ Ibid.

${ }^{35}$ Ibid., p. 82. 


\section{A. G. Debus}

life and being of all things, comes principally from the comets. ${ }^{36}$

Sibly again summarized the recent literature in his account of the earth. Thus he noted that the shape of the earth had been considered to be an almost perfect sphere "... till an accident engaged the attention of Sir Isaac Newton and Mr. Huyghens, who demonstrated, from the laws of hydrostatics, and the revolution of the Earth about its axis, that its figure was not a true sphere, but an oblate spheroid flatted toward the poles." 37 The further observation of Jean Richer (1630-1696) that his clock lost two minutes and twenty-eight seconds a day on the Island of Cayenne compared to its true time in Paris confirmed the views of Newton and Halley. ${ }^{38}$

In his discussion of the surface and the interior of the earth, Sibly examined the various theories of its origin and the effects of the Biblical flood, and reviewed the geological speculations of Descartes, Thomas Burnet (1643-1714), John Woodward (1665-1728), and William Whiston (1667-1752) ${ }^{39}$ Like many chemists before, he had a special interest in earthquakes and volcanic action. Here too he abstracted the current literature and he devoted much attention to the accounts of William Stukeley (1687-1765) and Giambatista Beccaria (1716-1781), who had ascribed these phenomena to electrical shocks. ${ }^{40}$ Sibly's interest in electricity extended to his investigation of meteorology, and he referred to the belief of John Canton (1718-1772) and Franklin that the aurora borealis was due to the presence of positive and negative electricity in the atmosphere. ${ }^{41}$

\section{ASTROLOGICAL TRUTH}

Sibly readily admitted that there were many methodologies employed by the scientists of his day. Like the contemporary mechanists, he used the clockwork analogy. However, the harmony of the macrocosm and the microcosm was even more fundamental for Sibly. He was interested in chemistry and knew the work of Priestley and Lavoisier, but at the same time he sought truth in the allegories of the alchemists and the earlier Paracelsians. He believed firmly that divine signs had been implanted in earthly substances at the time of the Creation and that it was the duty of the chemist to uncover them. The proof of these signatures could be shown in the resuscitation of plants from their ashes through palingenesis in the laboratory. ${ }^{42}$

Sibly also believed in magic. The scientist should be aware of the importance of natural magic for his own work, but he must also accept the existence of black magic. There were few who still believed in witchcraft, magic, or divination because of the general disbelief in the "... existence of spirits, the agency of the devil, and the appearance of ghosts or spirits of deceased men, upon which belief the practice of the black art entirely depends. But however incredulous the wisest critic may be, as to what has been related on this subject, certain it is, that such spirits really do exist, and

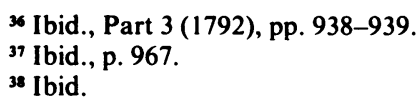

41 Ibid., p. 929.

42 Ibid., Part 4 [n.d.l, pp. 1114-1115. Recent studies of palingenesis include Jacques Marx. 'Alchemie et palingenesie', Isis, 1971, 62: 274-289; Allen G. Debus, 'A further note of palingenesis: the account of Ebenezer Sibly in the Illustration of Astrologv (1792)', ibid., 1973, 64: 226-230; François Secret. 'Palingenesis, alchemy and metempsychosis in Renaissance medicine', Ambix, 1979, 26: 81-92; Kenneth Rayner Johnson, 'Palingenesis', Hermetic Journal, autumn, 1980, no. 9, 8-16. 


\section{Scientific truth and occult tradition}

that confederacy and compact with them was in former times no uncommon thing." 43 Accordingly, Sibly discussed the evil and good spirits, the raising of the dead, and the incantations, charms, and talismans of some of the most notorious magicians of history.

But above all, Sibly was convinced that the study of astrology would greatly benefit mankind. He lamented the fact that this subject was ignored by most scholars because of the intellectual revolution of the preceding century. This event had resulted in a lack of recent research and the "too refined notions of modern philosophers." 44 But although he knew that many would reject his words as both obsolete and unfashionable, he was convinced of the truth of astrology and he urged his readers to consider the evidence he would present.

For Sibly, the concept of the grand unity of nature and its connexion with divinity was in danger of being lost. To be sure, all agreed that God had framed this world in terms of number, weight, and measure, but this had been accepted by philosophers other than the mechanists. It was necessary to accept first the fact that our world is based upon a perfect plan, one that operates harmoniously and sympathetically throughout its far reaches. Here superiors rule inferiors so that celestial bodies act on and influence all earthly substances by a regular inherent cause that was implanted at the Creation by God.45 If a model were needed, it should be that of the wheel. There are wheels within wheels in a divinely inspired motion that is perpetual. Here is to be found the path of communication from the celestial regions to our earth for life, spirit, power, virtue, magnetism, sympathy and antipathy, and attraction and repulsion. ${ }^{46}$

There is Biblical proof that since the time of the Creation, God has influenced the world. But He has also provided a means to forewarn man in the form of signs which he may learn to read and understand. Thus the signatures of plants and minerals will aid the physician, while earthquakes, pestilences, and the motions of the sun, the moon, the planets, and the stars must be properly understood if we are to be true students of our world. ${ }^{47}$ Indeed, a horoscope of the American colonies prepared for the time of the signing of the Declaration of Independence foretold the disastrous course of the ensuing war for England ${ }^{48}$ - and Sibly claimed to have predicted the fates of Louis XVI and Marie Antoinette..$^{49}$ In the Key to physic he went on to warn "Prussia, and all smaller German states, [to] beware; for the time will soon come, that Germany shall be no more." A later editor explained that "the accomplishment of this bold prediction, which the author did not live to see, will be found in the formation of the Confederation of the Rhine, in the suppression of the small states and annihilation of the Germanic circles, and the erection of the kingdoms of Bavaria, Saxony, Wirtemberg, and Westphalia, instead of them; but particularly when Francis II.

\footnotetext{
${ }^{43}$ Sibly, op. cit., note 7 above, Part 4 [n.d.], pp. 1059-1060.

4 Ibid., Part 1 (1784), p. 13.

is Ibid., p. 14.

46 Ibid., p. 15.

47 Ibid., p. 22.

Ibid., Part 4 [n.d.], plate opposite p. 1054. Of course, Sibly's calculations were made after the event.

क Sibly (1814), op. cit., note 11 above, p. 391, here referring to the 1786 edition of the Illustration ... of astrology.
} 
renounced the title of Emperor of Germany, Aug. 6, 1806.",50 We are all truly influenced by the stars. Indeed how can anyone seriously believe that they were created only to twinkle in the night? ${ }^{51}$

\section{MEDICINE FOR THE MICROCOSM}

In Sibly's world view, man is a very special being. Because of this, the physician must learn to understand the universe as a whole since man is affected by the macrocosm. Even more, man is truly a reflection of the entire universe about him. "In the creation of man, God seemed to deliberate and take counsel with himself how to epitomize and gather together all his works into so small a compass, to contract his book of creation into so small a volume. Hence he is called the microcosm or little world ...."\$2 Indeed, "Man is an admirable creature, the universe and epitome of the world, and the horizon of corporeal and incorporeal things." $\$ 3$

In the Creation, man's body was first formed. Then, with the breath of life, "he became a living soul." $\$ 4$ This process has been repeated in human generation. Here Sibly described at great length the various stages to be observed. The body is formed through the interaction of an elementary force (seed and the heat of the matrix) and the influence of the sun. Only later does the soul invest the body. ${ }^{55}$

But the Biblical account offered Sibly additional information on the original state of man and his present sorry state.

... before the fall, the seasons and elements were in one unalterable state of perfection and harmony; so the condition of man was not then under the power of the elements, but he was cloathed with purity and immortality as with a garment. The external gross elements had then no sway; and the astral powers, instead of inflaming his desires, contributed unto him the influences of like unto like, forming an union of delectable ideas between soul and body, which led to the unabated praise and adoration of his beneficient Creator.

... But departing from his innocency, by the secret insinuations infused into his mind by the fallen spirit Satan, he lusted after palpability in the flesh, turned his face to the elements, deserted his reason and his God, and fell from his ethereal state into all the perils of mortality and death. Having no longer all powers under his subjection, he became subject to sidereal and elementary influx, with his understanding darkened, and his mental faculties abridged .... s6 $^{56}$

\section{Sibly illustrated the effects of the fall of man in a series of four figures (Plate 3).}

The first represents the prime-eval state of man, with his hand lifted up to his head, denoting the seat of comprehensive sensibility, to which the light of reason and sense flowed from the mirror of the Deity, in whose image he was formed.

The second figure shews the elementary and astral influence in the prime-eval state of man, as having no action whatever internally, but falling on his exterior or back parts; whilst his face, turned to the light, received the beatific vision of immortality and life from the gate of heaven.

The third figure shews the internal action of the elementary and planetary influx after the fall, upon the vital parts of man, whence diseases and death follow in a direct and regular course. For, as the action of the stars on man are agents, and the elements of which he is composed patients, the same as in the outward world; so we find, as they are situated in the outward world at the time of birth, either as to strength or imbecility, so shall be the inward weakness or vigour of the vital parts of man born under them; and of such shall be the inbred quality of the disease thus implanted in our fallen nature to bring on corruptibility and death.

so Sibly (1814), op. cit., note 11 above, p. 392.

s1 Sibly, op. cit., note 7 above, Part 1 (1784), p. 26.

32 Sibly, op. cit., note 10 above, Part 2 (1812), p. 2.

s3 Ibid., p. 3. s4 Ibid., p. 2.

ss Ibid.

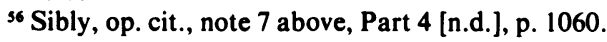




\section{Scientific truth and occult tradition}

The fourth figure is intended to shew a faint resemblance of an abandoned and more degenerated state of fallen human nature, when the will and passions of man are given up to vice, and contaminated with the gross or bestial quality of deadly sin and wickedness. He is led captive by an evil spirit, the agent of Lucifer, having his will darkened, and every spark of light extinguished, that could flow from the intellectual faculties of the soul, or from the collision of virtue and sense. ${ }^{37}$

It thus becomes evident that the action of the stars and the study of astrology is of utmost importance to the physician and surgeon.

The many invaluable discoveries lately added to the Pharmacopoeia, both from the vegetable and mineral worlds, are strong arguments of the necessity of regular practice, and of professional education, in forming the physician. But were the bulk of these gentlemen to consult a little more the planetary influences, both on vegetable and mineral substances, and apportion them in their prescriptions, according to the nature and constitution of the patient, uniformly consulting the effects of Saturn and the Moon in each crisis and critical day, I am persuaded that more immediate relief, in most cases where nature is not too far exhausted, may be afforded to the sick and languishing patient. Surgery too, which like a guardian angel steps forward to alleviate the perilous accidents of the unfortunate, would gain much improvement by the like considerations.

Sibly believed that all medicine must be grounded on anatomy, but, understandably, his anatomy was strongly coloured by his cosmic and chemical convictions. Man, woman, and the specific organs of the body are affected by the stars and their constellations. The stomach is analogous to the earth in the macrocosm, having similar sympathetic and antipathetic properties. As the sun attracts the humidity of the earth into the airy regions "as into the neck or higher part of an alembic," and is then condensed to fall down to the earth as rain, "so in the stomach, by the active quality of the microcosmical sun, his benevolent rays, and friendly heat, meat and drink are desired, and attracted into the stomach, for the nourishment of the whole body." 39 Sibly's explanation of digestion shows succinctly his use of alchemy and astrology.

The digestive faculty, which is the chief and most principal, (the others like handmaids attending it,) is hot and moist, nature's cook and principal workman, the archaeus and central fire which is this philosophical vessel, viz. the stomach, digesteth the victuals into a chaos, or confused mass, that so a natural separation may be made. It is under the influence of Jupiter, who furnisheth it with friendly heat and moisture, by the liver, (the microcosmical Jupiter,) chasing and heating the right side of the stomach. ${ }^{.0}$

The microcosmical sun is, of course, the heart, ${ }^{61}$ while the bladder "is the microcosmical ocean, into which all the rivers of the body discharge themselves." 62 Sibly readily accepted the circulation of the blood on the basis of the valves in the veins. Yet Sibly had read Harvey in depth and realized that he was somewhat less than the revolutionary figure others had suggested. Aware that Harvey had added some new facts in his work on generation, Sibly insisted nevertheless that in this volume Harvey had strayed little from Aristotle. ${ }^{63}$

More than once, Sibly compared men and the lower animals. ${ }^{64}$ To be sure, man is a quadruped and closely resembles the apes [he referred to Edward Tyson's (c. 1650-1708) study of the orangutan], but it would be wrong to make comparisons

57 Ibid., p. 1061.

ss Ibid., Part 1 (1784), p. 173.

s9 Sibly, op. cit., note 10 above, Part 2 (1812), pp. 10-11.

$\infty$ Ibid., p. 11.
61 Ibid., p. 12.

62 Ibid., p. 15.

${ }^{63}$ Sibly, op. cit., note 13 above, vol. 2, p. 315.

Ibid., p. 41. 


\title{
A. G. Debus
}

solely on the basis of anatomy. Man differs from the beasts in his possession of a soul and reason. Furthermore, man stands erect and has an august countenance turned toward heaven. ${ }^{65}$ Indeed "everything in both sexes points them out as the sovereigns of the earth; even the external appearance of man declares his superiority to other living creatures." Because of this truth and the fact that we are all descended from Adam, Sibly was led to digress on the evils of slavery, noting that all races are the same. Here he embraced the widespread eighteenth-century belief that Negroes lose their colour when no longer exposed to the tropical sun. ${ }^{67}$

Sibly believed that medicine originated in primitive man's observation that some natural substances cured illness. That this is so proves that medicine is based on universal sympathy. ${ }^{68} \mathrm{He}$ believed that like cures like, ${ }^{69}$ and he cited the Renaissance chemical physicians Paracelsus and Quercetanus regarding these cures. ${ }^{70}$ But Sibly did not prefer the mineral compounds of the Paracelsians to herbal remedies. Rather, he argued that it is only through vegetables that we obtain the purest minerals - a conclusion he had reached through his own chemical investigations in the laboratory.

\begin{abstract}
... there are no mineral substances in the bowels of the earth, whose virtues are not communicated to plants and herbs growing on the earth's surface: and that the correspondent virtues found in these herbs are infinitely more pure, innocent, balsamic, nutritive, and better adapted to medicine, than any gross or earthy particles whatever.... Indeed vegetables appear to be the medium contrived by an all-wise and omnipotent Creator, for selecting, concocting, and combining, the medical and occult virtues of the different substances found in the bowels of the earth, and for adapting their virtues by an easy and natural concoction to the alleviation of human infirmities; according to that passage in scripture which says, that the Lord hath caused medicine to grow out of the earth, and he that is wise will not abhor them, for with such doth he heal men, and taketh away their pains. Eccl. xxxviii. 4, 7. Whence I conclude, that all disorders incident to mankind are to be cured, preferably, and more elegantly, more safely, and certainly, by preparations from medical plants and herbs, than from any mineral substances whatever...."
\end{abstract}

But again, Sibly's words cannot be simply reduced to a case of chemical research since astrological knowledge is essential in the application of drugs. "Vegetables bear relation to the seven planets, and have form and affinity with the microcosm, or parts of man...."72

Sibly was particularly interested in preventive medicine and he referred repeatedly to rules for the preservation of health. He presented statistical evidence related to the life expectancy of man. He considered the period of old age to begin at forty ${ }^{73}$ and he cautioned those who would live long to avoid dangerous professions. Chemists are exposed to noxious exhalations "so charged with phlogiston as to be rendered unfit for expanding the lungs sufficiently.... ${ }^{74}$ Miners are not only hurt by unwholesome air,

as Sibly, op. cit., note 10 above, Part 2 (1812), p. 2.

"Sibly, op. cit., note 13 above, vol. 1, p. 21.

"Ibid., pp. 311-312. On this point see William Stanton, The leopard's spots: scientific attitudes toward race in America 1815-59. Chicago, University of Chicago Press, 1960.

Sibly, op. cit., note 11 above, p. 33.

" Ibid. "... sympathy and similitude are synonymous; and ... all substances which have resemblance by

Signature, have sympathy and agreement by nature, and serve for the conservation of each other."

ro Ibid.; the latter as Querintius.

"Ibid., p. 34.

2 Ibid., p. 35.

33 Ibid., p. 151.

${ }^{74}$ Sibly, op. cit., note 10 above, Part 2 (1812), p. 113. 


\title{
Scientific truth and occult tradition
}

but likewise by the particles of metal which adhere to their skin, clothes, \&c. . . . Lead and several other metals are likewise very pernicious to the health."7s Professions involving heavy labour tax the health while military men live under worse conditions than nearly anyone else. ${ }^{76}$ However, "nothing can be more contrary to the health and nature of man than a sedentary life." Scholars must exercise regularly, and Sibly recommended "that every person who follows a sedentary employment should cultivate a piece of ground with his own hand." 77

Sibly sought to maintain the natural harmony of the body and he emphasized temperance and moderation in all things. In addition to exercise, we all need a plentiful supply of air, sufficient sleep, and moderation in food.

\begin{abstract}
Men, not contented with satisfying the simple calls of Nature, create artificial wants, and are perpetually in search of something that may gratify them; but imaginary wants can never be gratified. Nature is content with little: but luxury knows no bounds. Hence the epicure, the drunkard, and the debauchee, seldom stop their career, till their money, or their constitution, fails: then, indeed, they generally see their error when too late. ${ }^{n}$
\end{abstract}

Rich diets cause gout and dropsy, while drunkenness results in consumption. ${ }^{79}$ Many of his male patients complained of impotency, and he warned all against the dangers of the venereal diseases and masturbation. ${ }^{80}$ Sea bathing was to be enjoyed, but with caution. To be sure, this might be of value in some cases, especially for "the inhabitants of populous cities, who indulge in voluptuousness, and lead sedentary lives", 81 and women and others "of a debilitated constitution and relaxed fibre" who need "the bracing qualities of cold water." caution young men against too frequent bathing; as I have known many fatal consequences result from the daily practice of plunging into rivers, and continuing there too long." 83

Unfortunately, a temperate life and preventive measures will not exterminate all disease. The physician must be able to recognize the afflictions of his patients - and for this reason Sibly listed the most prevalent diseases, described their symptoms, and offered the best methods of cure. As might be expected, some folk remedies - such as the use of millipedes to cure the whooping-cough - are to be found here. ${ }^{34}$ However, there is much common-sense medicine as well. Thus wounds are to be kept clean and covered with lint.85 And Sibly did not insist that he could cure all illness. Gout was ascribed to "excess and idleness", and he admitted "that there are no medicines yet known that will cure the gout." ${ }^{86}$ As for cancer, he was also unable to prescribe a sure cure.

75 Ibid., p. 114.

76 Ibid., pp. 114-115.

"Ibid., pp. 115-116.

"Sibly, op. cit., note 11 above, p. 182.

"Ibid., pp. 182-183.

* For sample cases (generally cured by Sibly's Solar Tincture) see ibid., pp. 354-360. See also Sibly, op. cit., note 10 above, Part 2 (1812), pp. 221-223.

"Sibly (1807), op. cit., note 12 above, p. 189.

22 Ibid., pp. 190, 192.

3 Ibid., pp. 191-192.

a Sibly, op. cit., note 10 above, Part 2 (1812), p. 146.

es Ibid., p. 186.

${ }^{26}$ Ibid., p. 165. 


\section{A. G. Debus}

This is one of those diseases for which no certain remedy is yet known. Its progress however may sometimes be retarded, and some of its most disagreeable symptoms mitigated, by proper application. One misfortune attending the disease is, that the unhappy patient often conceals it too long. Were proper means used in due time, a cancer might often be cured; but after the disorder has arrived at a certain height, it generally sets all medicine at defiance."7

If purging and bloodletting do not help and the tumour becomes large and hard,

it will be proper to extirpate it either by the knife or caustic. Indeed, when ever this can be done with safety, the sooner it is done the better. It can answer no purpose to extirpate a cancer after the constitution is ruined, or the whole mass of humours corrupted, by it. This however is the common way, which makes the operation so seldom suceed. Few people will submit to the extirpation till death stares them in the face...."

Throughout Sibly's medical works there is evidence of his knowledge of the recent literature. He discussed William Heberden's (1710-1801) fundamental paper on angina pectoris (1772) at great length and then went on to describe more recent accounts. ${ }^{89}$ In regard to diabetes, he referred to Matthew Dobson's (?-1784) recent discovery (1776) "that the urine seems to be entirely or very much divested of an animal nature, and to be largely impregnated with a saccharine salt, scarcely distinguishable from that obtained from the sugar-cane." 90 Even tooth decay was a matter of concern for him. Microscopic evidence showed clearly that

Animalcules are the most common causes of foul and rotten teeth. They attack the roots below the enamel, which they perforate, and in a short time form crustations or scales round the teeth, as hard as stones; but which are nothing more than a congeries or crustaceous shell, which these little animals inhabit, and are probably formed of the fine particles falling from the teeth during their perforations, cemented together by a glutinous slimy matter issuing from their own bodies, which are composed of ringlets like a worm.... These circumstances seem to be but little known to the generality of dentists and operators on the teeth; otherwise I am persuaded their mode of practice would be widely different. Instead of applying powders and dentifrices calculated to destroy these little worms, they prepare such as multiply and nourish them; ...91

Microscopic evidence convinced Sibly that his own Solar Tincture was the best method of destroying these creatures and restoring the health of teeth..$^{22}$

The ravages of the venereal diseases had posed a problem for the European medical community since the late fifteenth century, and mercury had been a favourite drug almost as long. Sibly objected to this remedy: "many people, on the first appearance of a gonorrhoea, fly to the use of mercury. This is a bad plan. Mercury is often not at all necessary in a gonorrhoea, and, when taken too early, it does mischief." 93 Far better is the mercury compound, corrosive sublimate $\left(\mathrm{HgCl}_{2}\right)$ which was introduced in Germany by Baron van Swieten (1700-1772) and in England by Sir John Pringle (1707-1782).94 But if this was better, it was still not what the medical community should be looking for. Once again Sibly favoured herbal remedies over mineral compounds. Here he noted that the American Indians were said to cure this class of disease through vegetable substances and

they do it with speed, safety, and success, by the use of vegetables only, and that without the least knowledge of mercury. Hence it becomes an object of considerable importance to discover a method of cure in this island, by the use of vegetables only, by making trial of all the various plants which are found

"7 Ibid., pp. 181-182.

Ibid., p. 182.

Sibly, op. cit., note 11 above, pp. 225-232.

Ibid., p. 221.
91 Ibid., p. 78.

92 Ibid., pp. 78-79.

${ }^{93}$ Sibly, op. cit., note 10 above, Part 2 (1812), p. 205.

Ibid., pp. 212-213. 


\section{Scientific truth and occult tradition}

in it. ... Indeed there can be no doubt, but plants of our own growth, ... would be found as efficacious in curing the venereal disease here, as those of America there; for it must be remembered that what will cure a patient of the venereal disease in one country will not have equal success if carried into another; a plain demonstration that every country produces that which is most congenial to the health of its own native inhabitants. ${ }^{95}$

In contrast to the incurable diseases, Sibly sounded a note of hope in the case of smallpox. Noting that inoculation had been known in Europe for more than half a century, he wrote that the practice had not become common until taken up by nonmedical men who specialized in this treatment. The results had been dramatic. While in the normal course of the disease some twenty to twenty-five per cent die, with inoculation "not one of a thousand" perishes. ${ }^{96}$ Posthumous editions of the English physician refer to Edward Jenner's (1749-1823) discovery of smallpox vaccination (1798).

VACCINE INOCULATION is the term for a practice lately introduced of inoculating persons with the matter drawn from pustules which rise upon the teats of cows: this is said (by its supporters) to prevent patients from ever taking the natural small-pox. It has so far succeeded, as to procure its inventor, Dr. Jenner, grants from the parliament of 30,500 1. sterling for the communication of his discovery.97

Nevertheless, physicians were to be cautioned about properly identifying the disease. Noting William Heberden's paper on the similarity between chickenpox and mild cases of smallpox, he warned against the possible confusion of the two. "From the great similitude between the two distempers, it is probable that, instead of the smallpox, some persons have been inoculated from the chicken-pox; and that the distemper which has succeeded had been mistaken for the small-pox by hasty or inexperienced observers." 98

Sibly's knowledge of recent medical discoveries was joined to his firm conviction that disease was due to astral influences. He also believed that diseases could be transplanted from one person to another, or from a person to an animal. This practice was at one time "in practice amongst witches and wizzards; and, I am confidently informed, is now frequently done in the more remote and unpolished parts of this island."99 The method consisted in the burying of images with ominous inscriptions and Hebrew words, but although many considered it to be magical, in reality it was due to natural sympathetic action.

Nor was Sibly above the realm of patent medicine. One of the results of his years of study had been the discovery of two basic medicines for men and women, his Solar and Lunar Tinctures.

That intended for the use of Man I call the SOLAR TINCTURE, as being congenial to the seminal functions and vital principles of his constitution. That adapted to Woman I call the LUNAR TINCTURE, as being calculated to act upon the menstrual and vegetative fluids, and as being com-

9s Ibid., p. 213.

96 Ibid., p. 135. See also, Peter Razzell, The conquest of smallpox, Firle, Sussex, Caliban Books, 1977.

97 Sibly, op. cit., note 10 above, Part 2 (1812), p. 136. On 2 June 1802, a committee of Parliament voted $£ 10,000$ to the king to be awarded to Jenner. On 29 July 1807 , there was a vote for an additional $£ 20,000$. See Charles Creighton, with additional material by D. E. C. Eversley, E. Ashworth Underwood, and Lynda Ovenall, $A$ history of epidemics in Britain, 2 vols., London, Frank Cass; New York, Barnes \& Noble, 1965, vol. 2, p. 567.

- Sibly, op. cit., note 11 above, p. 220.

9 Sibly, op. cit., note 7 above, Part 4 [n.d.], p. 1113. 


\section{A. G. Debus}

pounded of those elements which make up the frame and temperature of her body. The invention of these Tinctures hath been the result of a long and laborious application to the study of unveiled Nature of the properties of fire, air, earth, and water, in the propagation of animal and vegetable life, and in the composition of medicine; in which, though these elements form the PABULUM of the universe, yet the art of collecting, uniting, and assimilating them with the vital fluids, seems to be unknown among modern chemists, and has escaped the observation of medical science. The fixity of these Tinctures at once establishes their power and efficacy beyond all others; for they can never be affected by change of weather or climate, nor by heat or cold; nor will they suffer any diminution of their strength or virtue by remaining open, or uncorked; a circumstance which cannot be affirmed of any other fluid at present known, throughout the world. ${ }^{100}$

Needless to say, these medicines were described as useful for a wide variety of disorders (including chlorosis, gonorrhoea, infertility, scrofula, consumption, rheumatism, convulsions, asthma, dropsy, nocturnal emissions, and even hydrophobia). Numerous case histories and testimonials are given. In one case an eightyear-old girl was run over by a horse and carriage, "the wheels passing over her body." She appeared to be dead and Sibly was called for. "I avoided letting blood, but bathed the bruised parts thoroughly with the Solar Tincture, and introduced half a spoonful, undiluted, into her stomach." By the next morning, she was well enough to play with her companions. ${ }^{101}$ This wonderful medicine is far better than others that are commonly sold at a guinea an ounce. Sibly, however,

unwilling to adopt such examples, or to withhold from the afflicted in every line of life the benefits of his discovery, has determined to render it to the public at only $7 \mathrm{~s} .6 \mathrm{~d}$. the small, and 13s. the large, bottles, duty included, with ample directions in every complaint for which it ought to be administered. - A single bottle will in many cases perform a speedy cure, when, in the ordinary course of medical practice, it would occupy a month, and cost many pounds for unnecessary attendance, and excess of drugs. ${ }^{102}$

These successful medicines were still being sold forty years after his death.

\section{THE PROMISE OF MAGNETISM}

For Sibly, recent scientific investigations offered hope for the advance of medicine. The eighteenth century had witnessed great interest in electrical phenomena through the experiments of Francis Hauksbee (c. 1666-1713), Charles François du Fay (1698-1739), Stephen Gray (1666-1736), Franklin, Charles Augustin Coulomb (1736-1806), and others. Drawing on this literature, Sibly noted the similarity between the action of an electrified silk thread and the motion of a sensitive plant, and became convinced that electricity is a fundamental life property. It is, for instance, responsible for crystallization "which probably is only an incipient or imperfect vegetation." ${ }^{103}$ The medical use of electricity had already been studied by Tiberius Cavallo (1749-1809), and it had been shown to be beneficial in cases ranging from toothache to cancer and St. Vitus' Dance. ${ }^{104}$

Even more promising was animal magnetism. Sibly assured the reader that this had been discovered first by Paracelsus in the sixteenth century, ${ }^{105}$ but that it had become the centre of attraction more recently because of the work of Franz Anton Mesmer

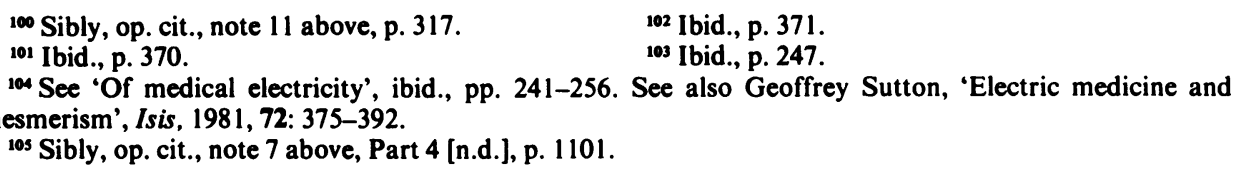




\section{Scientific truth and occult tradition}

(1734-1815). In many ways Mesmer's interests were similar to those of Sibly. His dissertation had been on the influence of the stars on the human body, and, like Sibly, he hoped to uncover a key to the universe. He wrote of an ethereal fluid pervading the world which - when properly understood - would explain universal phenomena such as magnetism, light, heat, electricity, and gravity. This was also to be the basis of medical reform since health was to be defined in terms of the proper flow of this fluid in the human body. Mesmer spoke of the body as analogous to a natural magnet with its attendant polarities. Normal polarity in the body assured a proper flow of the fluid; abnormality resulted in illness. The duty of the physician was to restore the natural polarity since only this would assure health and harmony between man and nature. Mesmer repeatedly produced convulsive "crises" in his Parisian salons and since cures were associated with crises, many of his contemporaries were convinced of the importance of his discovery. Mesmer soon had many converts who opened their own salons and claimed impressive cures.

Believing in the importance of his work, Mesmer sought scientific and medical approval from the Academy of Sciences and the Royal Society of Medicine. A royal commission was appointed that included scientists as well known as Franklin, Antoine Lavoisier (1743-1794), and Jean Sylvain Bailly (1736-1793), but their findings were no comfort to him. The Commissioners concluded that "Mesmer's fluid did not exist" and that the convulsions and other effects of mesmerizing could be attributed to the overheated imaginations of the mesmerists (1784). ${ }^{106}$

This official result led to a torrent of publications both defending and attacking Mesmer. Among the former may be listed Sibly's defence of animal magnetism in The key to physic and the occult sciences (1794) (Plate 2). Here Sibly briefly reviewed the career of Mesmer and noted that

The new system gained ground daily; and soon became so fashionable that the jealousy of the faculty was thoroughly awakened, and an application concerning it was made to the French government. In consequence of this, a committee was appointed to inquire into the matter, consisting partly of physicians and partly of members of the Royal Academy of Sciences, with Dr. Franklin at their head. Mesmer himself refused to have any communication with the committee: but his most celebrated pupil Deslon was less scrupulous .... ${ }^{107}$

It was Charles Deslon (1750-1786) who demonstrated the effects of animal magnetism to the commissioners. His principal method of application

... was by pressure of the hands or fingers on the hypochondria or lower regions of the stomach.

The effects of these operations upon Deslon's patients were very amazing. Some spit, coughed, sweat, and felt extraordinary heats in different parts of the body. Many had convulsions, which is what is called their crisis, \&c. - The commissioners after this determined to try the experiments themselves. For the fluid was totally imperceptible by any of the senses, and they could only ascertain its existence by its ultimately curing diseases, or by its observable effects upon the human body. ${ }^{108}$

\footnotetext{
${ }^{106}$ Robert Darnton, Mesmerism and the end of the Enlightenment in France, Cambridge, Mass., Harvard University Press, 1968, p. 64. Darnton provides a useful summary of Mesmer's work in France. He also notes the similarity of his work to that of Paracelsus (p. 14), a subject that is amplified by the present author in 'The Paracelsians in eighteenth century France: a Renaissance tradition in the age of the Enlightenment', Ambix. 1981, 28: 36-54.

107 Sibly, op. cit., note 11 above, p. 257

100 Ibid., p. 258.
} 


\section{A. G. Debus}

Sibly did not inform his readers of the negative report of the commissioners. Rather, he moved on to a nineteen-page quotation from the "ingenious Dr. Bell" whom he identified as England's greatest proponent of this system of medicine. ${ }^{109}$ Bell had been at the Parisian salons and he had later practised in Dublin and in London. The lengthy quotation presented by Sibly illustrates Bell's treatment of deafness, toothache, various eye disorders, epilepsy, scrofula, sore throat, palsy, rheumatism, consumption, nervous diseases, dropsy, asthma, apoplexy, nightmares, and somnambulism. For Bell, it was a matter of special importance for the physician to bring about a crisis in his patient since "The crises are an effort of nature against the disorder, endeavouring to dissipate the obstacles that are in the circulation, and to restore harmony or equilibrium in all parts of the body. Few diseases can be cured without a crisis ..."110

Although Sibly relied heavily on Bell's account for the practical medical procedures of animal magnetism, he discussed the theory himself in terms of sympathy and antipathy. He defined animal magnetism as ". . . a sympathy which exists between the magnet and the insensible perspiration of the human body, whereby an aether, or universal effluvia, is made to pass and repass through the pores of the cuticle, in the same manner as the electrical fluid passes through bodies, and by which many cures are performed." "111 For Sibly, the insensible perspiration is a fundamental factor in all medical treatment.

[It] issues from the pores of the body, which can only be discerned by means of a lens; being of so volatile and subtle a quality, that it passes through our garments with the utmost ease, particularly if woollen; and it even ascends through the bed-clothes, like a mist, in the greatest abundance when we are asleep, and the animal functions are at rest.

In this manner Nature, from all casual obstructions, endeavours to relieve herself; and, so long as diseases are recent, and of a mild tendency, they are usually carried off by this means, without requiring any aid from medicine. ${ }^{112}$

Advanced diseases are frequently evidenced by skin eruptions which indicate that even in these cases the body seeks to purify itself through the pores. But, important for an understanding of animal magnetism is the fact that the human pores which serve as a means of ridding the body of impurities are also essential as an entrance for the magnetic ethereal fluid. ${ }^{113}$

For Sibly, animal magnetism was the long-sought cause of sympathy and antipathy in nature.

That constant flux and reflux of the vital principles and corporeal humours in man ... produce those effects of sympathy and antipathy which become more natural and less miraculous; the atmospherical particle to each individual receives from the general fluid the proper attraction and repulsion. In the divers crossings of those individual atmospheres, some emanations are more attractive between two beings, and others more repulsive; so again, when one body possesses more fluid than another, it will repel; and that body which is less will make an effort to restore itself into equilibrium or sympathy with the other body. Robin Abraham Benhannes says, iron or ferruginous particles are every where, not only

\footnotetext{
109 Ibid., pp. 258-276. John Bell, "Professor of Animal Magnetism", wrote a number of books on subjects related to magnetism including An essay on somnambulism, or sleep walking produced by animal electricity and magnetism (1788), New system of the world and laws of motion (1788), and The general and particular principles of animal electricity (1792).

${ }^{110}$ Sibly, op. cit., note 11 above, p. 273.

111 Ibid., p. 256.

112 Ibid., pp. 348-349.

${ }^{113}$ Ibid., p. 349.
} 


\section{Scientific truth and occult tradition}

in the mineral world, but in our blood and bones; now, as the magnet attracts ferruginous particles, every thing of course is subservient to magnetism by the power of attraction or sympathy. ${ }^{114}$

Beyond this, animal magnetism is essential for our understanding of life itself.

... The vital principle, being a part of the universal motion, and obeying the common laws of the universal fluid, is consequently subjected to the impressions of the influences of celestial, earthly, and particular, bodies with which it is surrounded. That faculty or property of man, which renders him susceptible of all these impressions, is animal magnetism or animal electricity.

Man, being constantly in the universal and particular currents, is penetrated by them; the motion of the modified fluid by the different organizations of its constituent parts become tonical; it follows in that state the continuity of the body to the extreme parts. From these extremities of the body either flow out or pass in currents the universal fluid, when another body capable of receiving or returning them is placed in an opposite point.

1. There is a circulation formed between the currents passing in and out. 2. These currents are straitened and almost re-united in the same point; and these two causes concur together to increase successively the celerity of motion. ${ }^{115}$

The points at which the current leaves or enters the body are defined as poles analogous to those to be found in lodestones or artificial magnets. The currents themselves may be studied in terms of physics. They may "destroy or strengthen each other" or they may be "propagated and communicated at any distance whatever, either by continuities, connection of bodies and minds, as sympathy, or that of a fluid, such as air, water, sound, \&c." "If the current of animal electricity and magnetism concurs in its direction with the general magnetic current of the world, the increasing of all these currents is the general effect which results from it. These currents may again be reflected by looking-glasses, after the laws of light." 116

For Sibly, Mesmer's discovery was no less than Mesmer would have claimed himself: animal magnetism is a fundamental property of the universe. And like other discoveries in the past, this could also be applied to the benefit of mankind. Sibly understood health to be a state of harmony between the body and its environment. In such a case the magnetizer can do no harm to the body. But,

If on the contrary a body is not in harmony, that is to say, if it is in that state wherein proportions are disturbed, the habit it is in to experience that dissonance hinders it from being more sensible, and it becomes so by the application of animal electricity and magnetism; because that disposition and dissonance are increased. On these principles it is easy to conceive that sick persons drawing near their recovery become gradually insensible to animal electricity and magnetism; that absolute insensibility to its power constitutes the perfect cure. ${ }^{117}$

\section{CONCLUSION}

Historians of science and medicine have ignored Ebenezer Sibly. This decision is correct if our interests are to be limited to positive contributions alone. Sibly's work did not affect the development of late eighteenth- or early nineteenth-century science or medicine. We may perhaps compare him with Robert Fludd a century and a half earlier. Both authors sought truth in a mystical world view based on religious belief

\footnotetext{
114 Ibid., pp. 276-277.

11 Ibid., pp. 281-282.

116 Ibid., p. 282.

117 Ibid., p. 284
} 


\section{A. G. Debus}

and the harmony of the macrocosm and the microcosm. Both were acutely aware of recent developments in the sciences and both sought to correct a severely mechanistic interpretation of nature with their studies. Fludd was a member of the Royal College of Physicians and moved in Court circles. Sibly had taken his M.D. at Aberdeen and was to defend traditional medical education. ${ }^{118}$

But if Sibly attacked the quacks and repeatedly referred to his medical credentials, he was an outsider no less than Fludd had been. Fludd's work, however, had attracted a wide audience within the European intellectual community. Scholars of the calibre of Johannes Kepler (1571-1650), Marin Mersenne (1588-1648), and Pierre Gassendi (1592-1655) discussed his views at great length. On the other hand, although Sibly's volumes went through numerous editions over several decades, they were ignored by the medical and scientific establishment. One looks in vain for reviews of his works in medical and scientific journals of the period. The reason may be found in the different scientific climates of the early seventeenth and late eighteenth centuries. Fludd had lived in a period when there was, as yet, no dominant approach to the sciences. There were still many methodologies being proposed and debated. Hermeticists, alchemists, and astrologers participated in this debate no less than mechanists. The situation was different in the eighteenth century. Newtonian science was triumphant in the academies of Europe and the philosophers wished to have no relationship with those few who sought to reintroduce a mystical world view. It is little wonder that Sibly was ignored by his learned contemporaries.

Still, it would be quite incorrect to dismiss Sibly simply as an occultist. It is true that he was deeply convinced of the need to search for truth in the works of older alchemists, natural magicians, and astrologers. He wrote with conviction of the vital spirit and the anima mundi - and of sympathetic forces that bound together the great and small worlds. Yet, Sibly also felt comfortable with the most recent scientific journals and he sought to accommodate this research to his own world view. Heberden, Newton, Priestley, and Lavoisier were no less important to him than Aristotle, Hermes Trimegistus, Khunrath, and Paracelsus. Even more important, the recent work of Mesmer seemed to offer the most powerful proof of his own cosmic interpretation of man and nature.

Thus we find in Ebenezer Sibly the effort of a prolific British author to reform the mechanistic science and medicine of his own day through a new appreciation of philosophical systems that seemed to have been eradicated from the sciences a century earlier. Seen in this light Sibly may be understood less as a throwback to a "nonscientific" past than as an early English representative of the vitalistic scientific and medical philosophies of the Romantic period.

\footnotetext{
118 Sibly, op. cit., note 7 above, Part 1 (1784), p. 173. "It is not therefore the regular bred practitioners of either Physic or Surgery, that the author means to arraign; but that baneful description of empiricks and quacks, who now pervade the kingdom; and, like a swarm of locusts from the east, prey upon the vitals of mankind. These monsters in the shape of men, with hearts callous to every sentiment of compassion, have only fees in view. Governed by this sordid principle, they sport with life, unmoved amidst the bitter anguish and piercing groans of the despondent patient; till too far gone for human aid to restore, they abandon him to despair and death. For the sake of humanity, and the honour of a christian country, let the legislative power check this growing enormity!"
} 